Apidologie, 1986, 17 (2), 125-136

\title{
AMINO ACID AND SUGAR CONTENT OF THE NECTAR EXUDATE FROM LIMODORUM ABORTIVUM (ORCHIDACEAE). COMPARISON WITH EPIPACTIS ATROPURPUREA NECTAR COMPOSITION
}

\author{
Maria Salomé S. PAIS \\ Departamento de Biologia Vegetal, Faculdade de Ciências \\ R. da Escola Politécnica, 1294 Lisboa Codex, Portugal \\ H.J. CHAVES DAS NEVES and Ana Maria P. VASCONCELOS \\ Faculdade de Ciências e Tecnologia, Universidade Nova de Lisboa \\ 2825 Monle da Caparica, Portugal
}

\section{SUMMARY}

The amino acid content of nectary exudates from two orchids, L, abortivum (spur nectary) and $E$. atropurpurea (open nectary) were studied by means of capillary gas chromatography. Amino acids were analyzed as the corresponding $\mathrm{N}$-heptafluorobutyryl isopropyl esters. For each amino acid, enantiomeric composition was achieved by gas chromatography of the N-pentafluoropropionyl isopropyl esters on a capillary coated with the chiral liquid phase Chirasil-Val. Comparison of the amino acid contents of both nectars, as well as the enantiomeris composition of the particular amino acids, indicate evolutionary differences of both nectaries. Gas chromatographic analysis of the nectar sugars, supports the conclusion that the open nectary of Epipactis atropurpurea belongs to a more advanced evolutionary type compared to the spur nectary of Limolortum abortivum. The possible influence of the nectar composition on pollinators is discussed.

\section{INTRODUCTION}

Floral and extrafloral nectaries from epiphytic and terrestrial orchids have been studied by different authors (MAurizio, 1959 ; BASKIN and BLISS, 1969 ; ARditT et al., 1971). Particular attention has been paid to the sugar content. Studies by PERcival (1961) using paper chromatography showed that Epipactis atrorubens, $E$. helleborine and $E$. palustris are sucrose dominant. According to JeFFreY et al. (1970), the nectar of orchids can be classified as Fructose (F), Glucose (G) and Sucrose (S) dominant. Gas chromatography of the nectary exudates from 20 orchid species revealed that fructose, glucose, sucrose and raffinose are dominant over other mono- and oligosaccharides (BASKIN and BLISS, 
1969). Similar results were reported for the sugar content of the nectar of Epipactis atropurpurea (PAIS and Chaves DAS Neves, 1980).

The first reports on free amino acid content of nectars are due to ZiEgLER (1956). BAKER and BAKER (1977) have intensively studied the amino acid content of nectar exudates from different species. The role of the nectary exudate in attracting orchid pollinators has been emphasized since DaRwIN (1877), namely by VAN Der PiJl and Dodson (1966), Percival (1961), Baker and BAKER (1973) and Vogel (1983).

Our paper deals with the study of free amino acid and sugar content of the nectar exudate from Limodorum abortivum and its comparison with the nectar exudate of Epipactis atropurpurea.

\section{MATERIALS AND METHODS}

\section{Collection and Storage of Nectars}

The nectary exudates from Epipactis atropurpurea and Limodorum abortivum were collected by means of a glass capillary from 30 to 40 plants until a volume of $3 \mathrm{ml}$ was obtained. The nectar was immediately frozen after collection, freeze-dried, and stored under vacuum until further use.

\section{Materials}

All solvents used were obtained from E. Merck (Darmstadt) and purified by fractional distillation after appropriate drying. Hexamethyldisilazane (HMDS), trimethylchlorosilane (TMCS), pyridine, ethanethiol, heptafluorobutyric anhydride (HFBA) and pentafluoropropionic anhydride (PFPA) were chromatographic grade from Pierce Chemical Co. (Rockford, ILL.) and used without further purification. Standard amino acids were obtained from Supelco and cycloleucine was purchased from Aldrich Europe. The solutions of $\mathbf{H C l}$ in isopropyl alcohol were prepared in a volumetric flask by adding the appropriate amount of acetyl chloride (E. Merck, Darmstadt) to isopropyl alcohol, in an ice bath. OV-101 was obtained from Alltech Associates.

\section{Instruments}

Capillary gas chromatography was performed with a Pye Unicam instrument, Model 204, equipped with a splitter and a flame ionization detector (FID). Hydrogen was used as carrier gas, $\mathrm{U}=25 \mathrm{~cm} / \mathrm{s}$, split ratio $1: 60$. Analysis was carried out on a $25 \mathrm{~m} \times 0.18 \mathrm{~mm}$ i.d. borosilicate glass capillary coated with OV-101 according to the method described by ScHOMBURG et al. (1979). Enantiomer separations were achieved on a $25 \mathrm{~m} \times 0.25 \mathrm{~mm}$ glass capillary coated with ChirasilVal. Quantitative calculations were carried out with a Spectra Physics computing integrator Model SP 4100 . Response factors were calculated relative to $\mathrm{N}$-heptafluorobutyryl cycloleucine isopropyl ester as internal standard. GC/MS experiments were executed with a Shimadzu QP-1000 instrument.

\section{Isolation of Amino Acids and Sugars from L. abortivum}

The initial volume of the nectar was reconstituted by addition of the corresponding amount of deionized water. From this solution a known weight $(0.640 \mathrm{~g})$ was transferred to a $10 \mathrm{ml}$ volumetric 
flask, $0.100 \mathrm{ml}$ of a $4 \mathrm{mg} / 10 \mathrm{ml}$ solution of cycloleucine were added and the volume completed to $10 \mathrm{ml}$ by addition of deionized water. The solution was passed through a column of the cationic exchanger Dowex $50 \mathrm{~W}-\mathrm{X} 8$, the column was washed with approximately four times its volume of deionized water and the aqueous solutions collected and evaporated to dryness in a rotary evaporator. Weight of the sugar-containing residue was $0.108 \mathrm{~g}(16.9 \%)$.

The amino acids retained on the resin were eluted from the column with approximately four times its volume of a $4 \mathrm{M} \mathrm{NH}_{4} \mathrm{OH}$ solution. The ammoniacal solution was collected and evaporated to dryness in a rotary evaporator $(0.022 \mathrm{~g}, 3.4 \%)$.

\section{Isolation of Amino Acids and Sugars from E. atropurpurea}

The freeze-dried nectar was treated as above. A starting weight of $0.549 \mathrm{~g}$ afforded $0.176 \mathrm{~g}$ of a sugar-containing residue $(32 \%)$ and $0.036 \mathrm{~g}$ of an amino acid-containing residue $(6.5 \%)$.

\section{Derivatization of the Sugars}

The sugars were derivatized to the corresponding TMS ethers by reaction with N,O-bis (trimethylsilyl) trifluoroacetamide (BSTFA) in dimethylformamide according to a previously described procedure (PaIs and Chaves das Neves, 1980).

\section{Derivatization of Amino Acids}

The residue containing the free amino acids was dissolved in a minimal amount of water and transferred to a volumetric flask and the volume completed to $10 \mathrm{ml}$ by addition of deionized water. A, 0.250 to $0.500 \mathrm{ml}$ aliquot was transferred to a teflon-lined screw cap derivatization flask, the solvent evaporated under a light stream of nitrogen. $0.250 \mathrm{ml}$ of $4 \mathrm{M} \mathrm{HCl}$ in isopropyl alcohol and $0.010 \mathrm{ml}$ of ethanethiol were added to the residue and heated at $110^{\circ}$ for $30 \mathrm{~min}$. in the closed vial. After cooling to room temperature, the solvent was evaporated under a light stream of nitrogen. To the residue $0.200 \mathrm{ml}$ of dichloromethane, $0.100 \mathrm{ml}$ of HFBA and $0.010 \mathrm{ml}$ of ethanethiol were added. The flask was closed and heated at $150^{\circ}$ for 15 min. For analysis of histidine, the residue resulting from the evaporation of the solvent under a light stream of nitrogen was treated at $150^{\circ}$ for $20 \mathrm{~min}$. with $0.250 \mathrm{ml}$ of benzene and $0.050 \mathrm{ml}$ of ethyl pyrocarbonate. The solution was concentrated to $0.005 \mathrm{ml}$ and directly used for gas chromatographic analysis. An identical procedure was used for the preparation of the $\mathrm{N}$-pentafluoropropionyl isopropyl esters as required for enantiomer separation.

\section{RESULTS AND DISCUSSION}

As inherent constituents of a cell, amino acids represent more than $50 \%$ of its dry weight, mainly as building blocks of proteins. They are not only structural elements of the cell but also act as vehicles of selective transport or as messenger substances, nutrients, intermediates in metabolism and biosynthetic precursors. They play a major role in plant physiology and are important metabolic intermediates. Compared to other methods, capillary gas chromatography offers the advantages of high analysis speed, high sensitivity, high resolving power and great versatility of the instrument, together with its ability of on-line coupling to a mass spectrometer for rapid identification of unknowns. It requires, however, the previous preparation of volatile derivatives (for a revision see FRANK, 1985). 

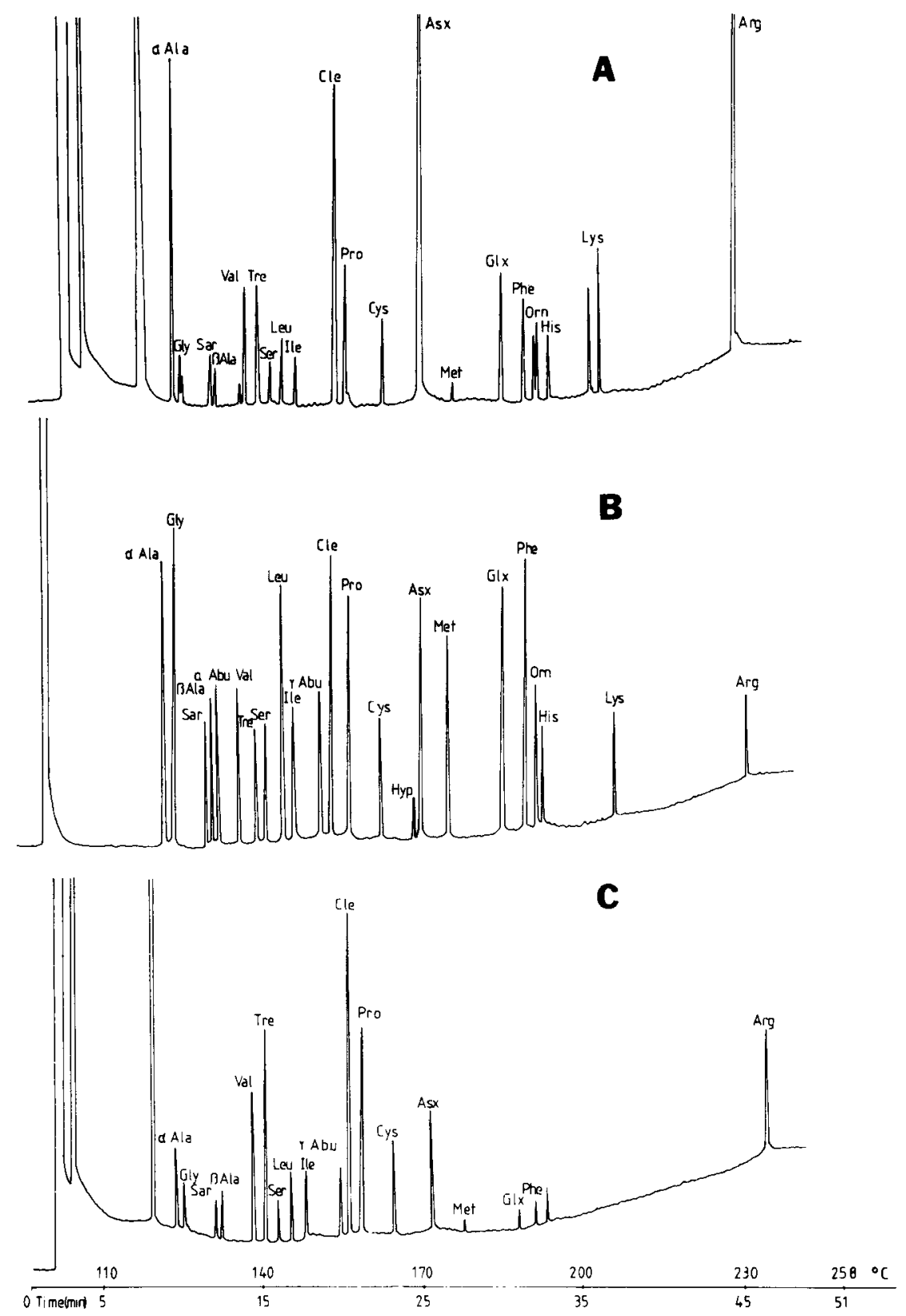

FIG. 1. - Gas chromatographic separation of nectar amino acids as the $N$-heptafluorobutyryl isopropyl esters (histidine as $\mathrm{N}^{1 \mathrm{~m}}$-ethoxycarbonyl derivative)

Column : WCOT, $25 \mathrm{~m} \times 0.25 \mathrm{~mm}$ i.d., coated with OV-101. Carrier gas : $\mathrm{H}_{z} ; \mathrm{U}=25 \mathrm{~cm} / \mathrm{s}$; split ratio : $1: 60$; attenuation $1: 32$. A - E. atropurpurea; B - chromatogram of standard amino acids; C - L. abortivum. 
For many years, floral nectars were treated as if they simply were a solution of sugars in water. However, the occurrence of free amino acids in nectars seems to be universal among nectariferous plants, possibily of taxonomic value (BAKER and BAKER, $1973 \mathrm{a}, \mathrm{b}$ ).

The amino acids of the nectar solutions were analyzed as the corresponding $\mathrm{N}$-heptafluorobutyryl isopropyl esters, or as the $\mathrm{N}$-pentafluoropropionyl isopropyl esters for enantiomer separation. Histidine was analyzed as the corresponding $\mathrm{N}^{\mathrm{im}}$ ethoxycarbonyl derivative. All the amino acids could be separated in a single run on a WCOT column coated with OV-101 (Fig. 1). The results are summarized in Table 1 . When the relative concentrations are considered, a characteristic pattern of amino acids is obtained for each of the nectary types.

TABL. 1. - Amino acid content $(\mathrm{mg} / 100 \mathrm{ml}$ ) of the nectars of Epipactis atropurpurea (open nectary) and Limodorum abortivum (closed nectary), as analyzed by capillary gas chromatography

\begin{tabular}{l|c|c}
\hline \multicolumn{1}{c|}{ Amino acid } & E. atropurpurea & L. abortivum \\
\hline Alanine & 0.40 & 0.09 \\
Glycine & 0.05 & 0.05 \\
Sarcosine & 0.08 & 0.13 \\
B-Alanine & 0.10 & 0.20 \\
Valine & 0.26 & 0.47 \\
Threonine & 0.22 & 0.47 \\
Serine & 0.11 & 0.13 \\
Leucine & 0.08 & 0.13 \\
Isoleucine & 0.15 & 0.33 \\
Proline & 0.25 & 0.53 \\
Cysteine & 0.89 & 1.20 \\
Aspartic acid/Asparagine & 1.48 & 0.40 \\
Methionine & 0.38 & 0.03 \\
Glutamic acid/Glutamine & 0.27 & 0.05 \\
Phenylalanine & 0.20 & 0.07 \\
Ornithine & 0.26 & 0.12 \\
Lysine & 0.53 & - \\
Histidine & 0.25 & - \\
Arginine & 4.50 & 1.87 \\
$\gamma$-Aminobutyric acid & - & 0.05 \\
Total & 10.46 & 6.32 \\
\hline \hline
\end{tabular}

As can be seen in Fig. 2, there are considerable differences between the amino acid patterns of both nectars. While in the open nectary of $E$. atropurpurea the more functionalized amino acids predominate, in the nectar of $L$. abortivum, which possesses a spur nectary, the less functionalized amino acids dominate the amino acid spectrum. Although seasonal differences in the concentration of a particular amino acid have been observed during a three year study of both nectars, the described amino acid pattern was constant and characteristic. A very 


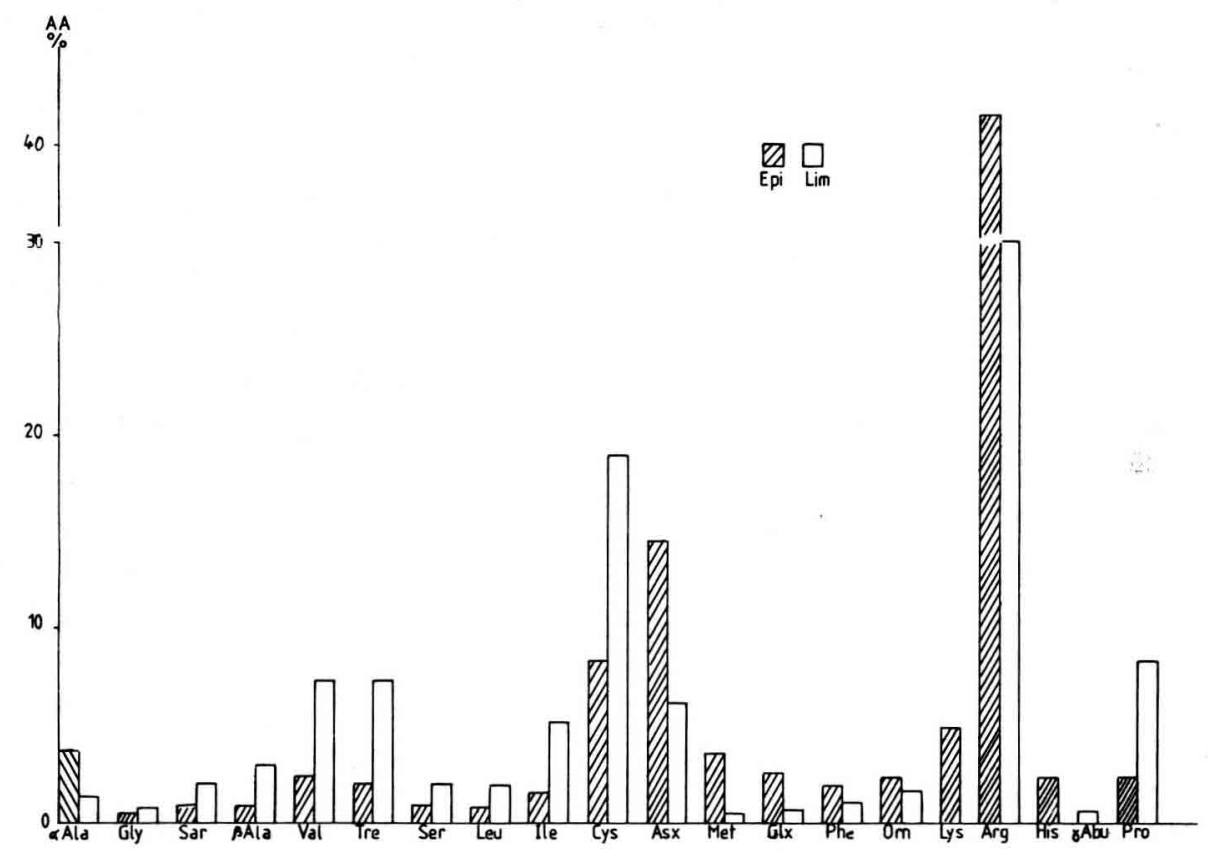

FIG. 2. - Comparison between the amino acid distribution (\%) in the nectaries of orchids

interesting result is the presence of D-amino acids in both nectars. D-glutamic acid is analyzed in both nectars with a high relative enantiomeric concentration. An unexpectedly high amount of D-alanine was found in the nectar of $E$. atropurpurea. D-cystein was exclusively present in the nectar of Epipactis atropurpurea. In the nectar of $L$. abortivum in the other hand, D-isoleucine has been exclusively identified (Table 2 ).

TABL. 2. - Relative percent enantiomeric concentrations of D-amino acids analyzed as the corresponding $N$-pentafluoroproprionyl isopropyl esters, in the nectars of $\mathrm{E}$. atropurpurea and $\mathrm{L}$. abortivum

\begin{tabular}{l|c|c}
\hline \hline Amino acid & $\begin{array}{c}\text { E. atropurpurea } \\
(\%)\end{array}$ & $\begin{array}{c}\text { L. abortivum } \\
(\%)\end{array}$ \\
\hline $\begin{array}{l}\text { D-Alanine } \\
\text { D-Isoleucine }\end{array}$ & 96.4 & 38.6 \\
D-Glutamic & - & 12.6 \\
D-Cysteine & 33.6 & 27.4 \\
D-Lysine & 30.4 & - \\
D-Methionine & traces & traces \\
\hline \hline
\end{tabular}


A major difference was found by comparison of the sugar contents of both nectars. The nectars of Limodorum abortivum is largely dominated by sucrose, with both fructose and glucose present in small amounts, mannitol, sorbitol and lactose being present only in traces (Fig. 3). This contrasts openly with the more complex composition of the nectar from E. atropurpurea (PAIS and Chaves DAS Neves, 1980).

From our results we may conclude that nectars of both species are very rich in amino acids (19 different amino acids for $E$. atropurpurea, 18 for $L$. abortivum). The total amino acid-containing residue is $6.5 \%$ of the total

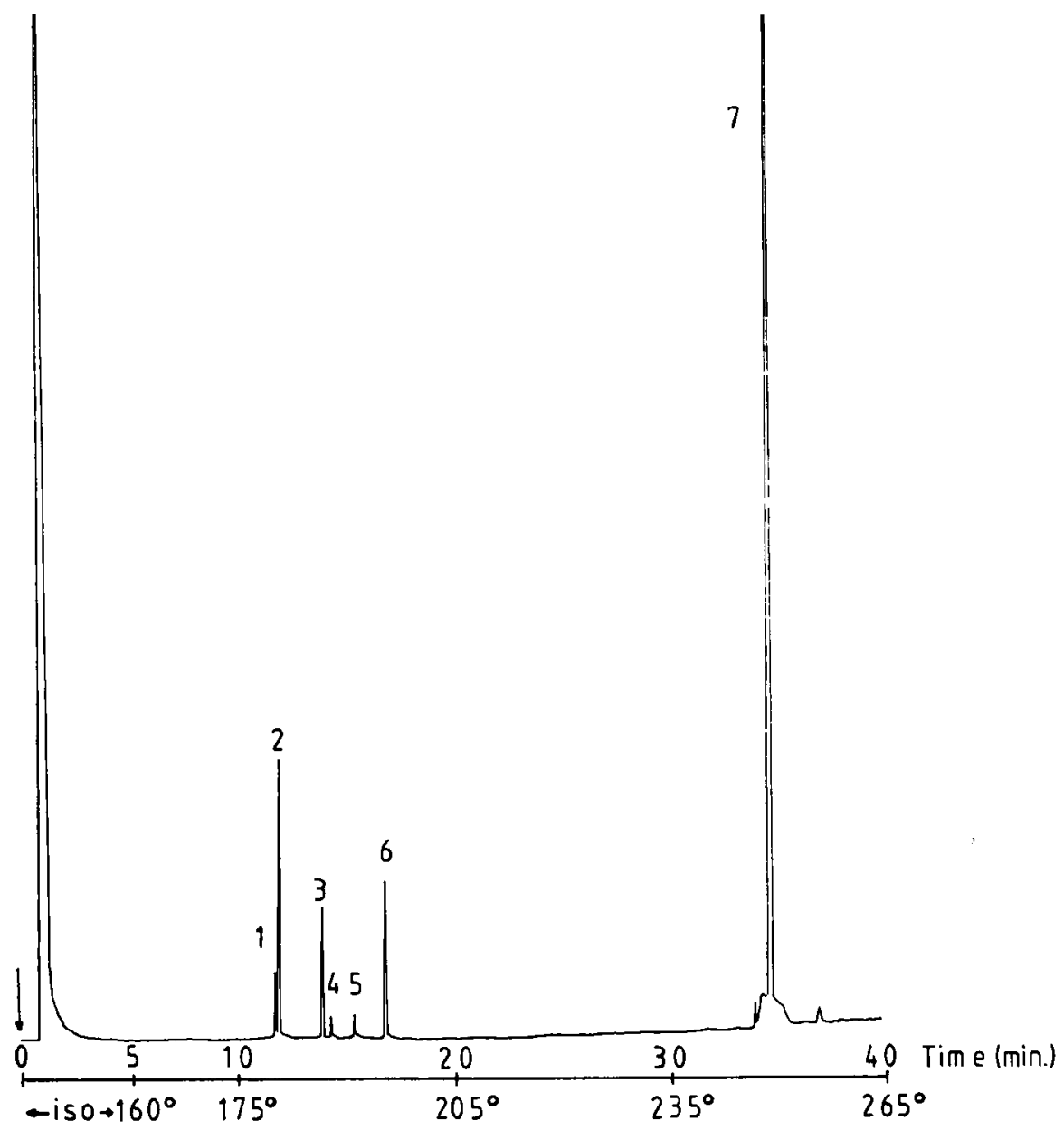

Fig. 3. - Gas chromatographic analysis of the sugars in the nectar of L. abortivum

Sugars as the trimethylsilyl ethers : 1 and 2 - Fructose; 3 - $\alpha$-Glucose; 4 - Mannitol; 5 - Sorbitol ; 6 - $\beta$-Glucose ; 7 - Sucrose. 
nectar weight for $E$. atropurpurea and $3.4 \%$ for $L$. abortivum. Lysine and histidine are detected only in $E$. atropurpurea. The more significant difference seems to be correlated with the presence of D-amino acids. It is interesting to note that while D-glutamic acid is present in significant amounts in both nectars together with a high relative enantiomeric concentration of D-alanine ( 96.4 and 38.6 respectively for $E$. atropurpurea and $L$. abortivum), D-cysteine was exclusively detected in the former, while D-isoleucine could only be detected in the latter.

To the best of our knowledge, no report exists on the relative amounts of $\mathrm{D}$-amino acids in nectars from different species or genera. It will be interesting to check if differences in D-amino acids can contribute to tracing taxonomic relationships between genera or/and type of nectaries (spur or open nectaries).

According to BAKER and BAKER (1973 b) higher amino acid scores are related to increasing evolutionary advancement. If the amino acid concentration of nectars, as previously reported by BAKER and BAKER (1973 b) can be related to the evolution degree of the nectaries, our results would account for a less evolved nectary in $L$. abortivum $(6.3 \mathrm{mg} / 100 \mathrm{ml}$ total amino acid concentration) when compared to the open nectary of $E$. atropurpurea $(10.5 \mathrm{mg} / 100 \mathrm{ml})$. This trend is in agreement with the results obtained in the analysis of both nectars. The sugar-containing residue amounts to $32 \%$ of initial nectar weight from $E$. atropurpurea and only to $16.9 \%$ in the nectar from L. abortivum. In this context, nectaries of $L$. abortivum may be less evolved than those of E. atropurpurea. Nectar from L. abortivum contains mainly sucrose (Fig. 3), while that from $E$. atropurpurea is of the fructose-glucose type (PAIS and Chaves Das Neves, 1980). HARBorne (1982), based on the sugar composition of nectars, suggested that, in angiosperms, an evolutionary trend can be established from nectars of the sucrose type to nectars of the fructose-glucose type.

It has also been reported that the nectars of the sucrose type are mainly secreted by spur nectaries, while the nectars of the fructose-glucose type would originate from open nectaries (PERcival, 1961). Our results on Limodorum abortivum and Epipactis atropurpurea nectars are in full agreement with this.

A correlation between the sugar content of nectaries and the kind of pollinators has been suggested (Percival, 1965; BAKer and BAKER, 1975). According to these authors, butterflies would prefer nectars containing 21-48\% sugar, while honey bees would prefer nectars with a sugar concentration range within 10 to $74 \%$. On the other hand, bumble bees, would favor nectars the sugar concentration of which is in the range of 30 to $40 \%$. According to this point of view, the nectars of both $E$. atropurpurea and $L$. abortivum would be suitable for all three kinds of pollinators. The fact that the overall amino acid content of the nectar of $L$. abortivum is lower than in E. atropurpurea suggests that the 
former may be preferentially collected by bees while the latter would be suitable for bees and butterflies. On this subject WALlER (1972) has noticed that bees collect preferentially nectars with sucrose concentrations of 30 to $50 \%$. This is the case with $L$. abortivum. According to the observations of GodfERY (1933) the pollinators of $L$. abortivum are different kinds of bees. On the other hand, bumble bees (GODFERY, 1933) and honey bees have been described as pollinators of E. atropurpurea (WIEFELSPÜTZ, 1970).

\section{CONCLUSION}

High resolution power, speed of analysis and high sensitivity of capillary gas chromatography make this method the analytical tool of choice for the analysis of complex mixtures. Capillary gas chromatography was thus used for the determination of amino acids and sugars, after adequate derivatization, in the nectars of Epipactis atropurpurea and Limodorum abortivum. The former possesses a nectary of the open type in contrast with the spur type nectary of the latter. In agreement with observations of others our results seem to indicate a difference in the evolutionary stage between the orchids, L. abortivum belonging to a lower evolved type. According to HARBORNE (1982), lower scoring families tend to be bee-pollinated, bees being able to obtain nitrogen from sources other than nectar, such as pollen. Comparative discussion of the amino acid concentrations in both nectars clearly shows important quantitative and qualitative differences in amino acid composition. These differences can be correlated to the nectary type (open or spur) in each case, in agreement with the observations of other authors. Major differences in sugar composition were also observed. While the nectar of $E$. atropurpurea follows the fructose-glucose pattern, as previously described, the nectar of $L$. abortivum belongs to the sucrose type.

Different kinds of bees have been described as pollinators of $L$ abortivum (GodFERY, 1933), while bumble bees and honey bees seem to be pollinators of E. atropurpurea. Our results suggest that systematic comparative studies of nectar composition, by powerful analytical techniques as capillary gas chromatography could prove invaluable in the study of pollinator-plant relations as well as in the chemotaxonomic area. 


\section{RESUMÊ}

\section{TENEUR EN ACIDES AMINES ET EN SUCRES \\ DU NECTAR DE LIMODORUM ABORTIVUM (ORCHIDACEA). COMPARAISON AVEC LA COMPOSITION DU NECTAR D'EPIPACTIS ATROPURPUREA}

La teneur en acides aminés du nectar de 2 orchidées, Epipactis atropurpurea (nectaire ouvert) et Limodorum abortivum (nectaire à éperon) a été étudiée par chromatographie en phase gazeuse sur colonnes capillaires, après avoir été isolés par échange d'ions (Dowex $50 \mathrm{~W}-\mathrm{X} 8$ ). Afin d'obtenir des dérivés volatiles, les acides aminés ont été transformés en $\mathrm{N}$-heptafluorobutyryl isopropylesters. Ceux-ci ont pu être entièrement séparés en 1 seul passage chromatographique sur 1 capillaire en verre de $25 \mathrm{~m} \times 0,18 \mathrm{~mm}$ imprégné de OV-101 (Fig. 1). L'analyse a été réalisée par la méthode de l'étalon interne, après calcul des coefficients de réponse individuels vis-à-vis de la cycloleucine utilisée comme étalon interne. L'histidine a été analysée sous forme du dérivé $\mathrm{N}^{\mathbf{i}}$-ethoxycarbonyl correspondant. Ces acides aminés ont été identifiés individuellement par comparaison avec des échantillons authentiques, par les temps relatifs de rétention et par chromatographie en phase gazeuse-spectrométrie de masse (GCMS). Les résultats sont présentés dans le tableau 1. La séparation des acides aminés $\mathbf{D}$ et $\mathrm{L}$ a été réalisée sur un capillaire de verre de $25 \mathrm{~m} \times 0,25 \mathrm{~mm}$ imprégné d'une phase liquide chirale de chirasil-val et la concentration énantiomérique relative a été calculée à partir de l'aire des pics (Tabl. 2). Un modèle caractéristique est obtenu pour chacun des types de nectar (Fig. 2). Les acides aminés les plus fonctionnalisés prédominent dans le nectar d'E. atropurpurea. Un résultat très intéressant est la présence dans les 2 nectars de quelques acides aminés-D qui ne sont pas les mêmes à l'exception de l'acide glutamique-D, présent dans les 2 nectars avec une composition énantiomérique plus ou moins équivalente. On a trouvé une quantité élevée inattendue d'alanine-D dans le nectar d'E. atropurpurea. Une différence majeure entre les 2 nectars est la composition en sucres, déterminée par la chromatographie gaz liquide capillaire des esters TMS. Le nectar de L. abortivum est largement dominé par le saccharose tandis que celui d'E. atropurpurea a une composition plus complexe (Pais et Chaves das Neves, 1980).

De ces résultats nous pouvons conclure que les deux nectars sont qualitativement riches en acides aminés; 19 acides aminés ont été identifiés chez $E$. atropurpurea et 18 chez $L$. abortivum. La concentration totale en acides aminés est respectivement de 10,46 et $6,32 \mathrm{mg} / 100 \mathrm{ml}$. Si les concentrations en acides aminés reflètent le degré d'évolution des nectaires (BAKER and BAKER, $1973 \mathrm{~b}$ ), alors nos résultats indiquent que le nectaire de $L$. abortivum est moins évolué que celui $\mathrm{d} E$. atropurpurea. Le fait que la teneur totale en acides aminés du nectar de $L$. abortivum soit plus faible que celle du nectar $\mathrm{d}^{\prime} E$. atropurpurea suggère que le premier est récolté de préférence par les abeilles, tandis que le second convient à la fois aux abeilles et aux papillons.

La puissance de résolution élevée, la vitesse d'analyse et la haute sensibilité de la chromatographie en phase gazeuse sur capillaires permet d'introduire des méthodes plus précises pour établir la teneur en acides aminés des nectars. Pour la première fois, l'ensemble des acides aminés des nectars d'orchidées est établi en détail. L'utilisation de nouvelles phases liquides chirales a permis pour la première fois d'identifier des acides aminés-D dans les nectars. Des études comparatives systématiques de la composition du nectar, à l'aide de techniques analytiques puissantes telles que la chromatographie en phase gazeuse sur capillaires pourrait se montrer très précieuse dans l'étude des relations pollinisateur-plante et dans le domaine de la chimiotaxonomie.

\section{ZUSAMMENFASSUNG}

\section{AMINOSAUREN- UND ZUCKERGEHALT DER NEKTARAUSSCHEIDUNG} VON LIMODORUM ABORTIVUM (ORCHIDACEAE).

\section{VERGLEICH MIT DER NEKTARZUSAMMENSETZUNG BEI EPIPACTIS ATROPURPUREA}

Der Aminosäurengehalt von Nektarexsudaten der beiden Orchideen Epipactis atropurpurea (offene Nektarien) und Limodorum abortivum (Nektarsporn) wurde mit Hilfe von Kapillar- 
Gasflüssigkeits-Chromatographie nach der Isolation durch Ionenaustausch (Dowex $50 \mathrm{~W}-\mathrm{X} 8$ ) untersucht. Um auch flüchtige Derivate auffangen zu können, wurden die Aminosäuren in N-Heptafluorobutyryl-Isopropylester transformiert. Diese können mit einem chromatographischen Durchgang in einer $25 \mathrm{~m} \times 0,18 \mathrm{~mm}$ i.d. Glaskapillare beschichtet mit OV-101 (Fig. 1) isoliert werden. Die Analyse wurde mit Cycloleucin als internem Standard durchgeführt. Histidin wurde als $\mathrm{N}^{1 \mathrm{~m}}$-EthoxycarbonylDerivat analysiert. Die Identifikation der individuellen Aminosäuren wurde durch Vergleich der rel. Retensionszeiten mit authentischen Proben und durch GCMS durchgeführt. Die Ergebnisse sind in Tab. 1 zusammengestellt. Die Separation von D- und L-Aminosäuren wurde durch eine $25 \mathrm{~m} \times 0,25 \mathrm{~mm}$ Glaskapillare beschichtet mit der chiralen Flüssigkeitsphase von Chirasil-Val durchgefïhrt und die relative enantiomerische Konzentration von den maximalen Flächenwerten errechnet (Tab. 2). Ein charakteristisches Muster wurde für jeden Nektarientyp aufgezeichnet (Fig. 2). Die mehr funktionalisierten Aminosäuren dominieren im Nektar von E. atropurpurea. Ein sehr interessantes Ergebnis ist die Präsenz von einigen D-Aminosäuren in den beiden Nektaren. Diese sind unterschiedlich in jedem Nektar mit Ausnahme von D-Glutaminsäure, die in beiden in mehr oder weniger äquivalenter enantiomerischer Komposition vorhanden ist. Eine unerwartet hohe Menge von D-Alanin wurde im Nektar von $E$. atropurpurea gefunden. Ein bedeutender Unterschied zwischen den beiden Nektaren wurde in der Zuckerzusammensetzung gefunden, die mit Hilfe der Kapillar-Gasflüssigkeits-Chromatographie der TMS Äther bestimmt wurde. Der Nektar von $L$. abortivum wird besonders von Sacharose dominiert im Gegensatz zu der mehr komplexen Zusammensetzung des Nektars von E. atropurpurea (PAIS and Chaves das NeVEs, 1980).

Aus diesen Ergebnissen folgern wir, daß beide Nektare reich an Aminosäuren sind. Für $E$. atropurpurea wurden 19 und für L. abortivum wurden 18 verschiedene Aminosäuren identifiziert. Die gesamte Aminosäurekonzentration war jeweils 10,46 und 6,32 (mg/100 ml). Falls die Aminosäurekonzentration in Beziehung zum Evolutionsgrad der Nektarien gesetzt werden könnte (BAKER and BAKER, 1973 b), würden unsere Ergebnisse ein weniger evoluiertes Nektarium bei L. abortivum als bei $E$. atropurpurea aufzeigen. Die Tatsache eines kleineren totalen Aminosäuregehalts im Nektar von L. abortivum als im Nektar von $E$. atropurpurea läßt darauf schließen, daß ersterer vornehmlich von Bienen gesammelt wird während der andere Bienen und Schmetterlingen zugeschrieben werden kann.

Durch die hohe Auflösung, die Geschwindigkeit der Analyse und die hohe Sensitivität der Kapillar-Gasflüssigkeits-Chromatographie können präzisere Methoden der Bestimmung des Aminosäurengehalts von Nektarienexsudaten eingeführt werden. Die Gesamtheit der Aminosäuren des Orchideen-Nektars wurde zum ersten Mal in Einzelheiten bestimmt. Durch den Gebrauch der neuen chiralen Flüssigkeitsphasen konnten zum ersten Mal die D-Aminosäuren in den Nektaren identifiziert werden. Systematische vergleichende Studien der Nektarzusammensetzung durch effektive analytische Techniken wie Kapillar-Gaschromatographie könnten für die Erforschung von BestäuberPflanze-Beziehungen wie auf chemotaxonomischem Gebiet wertvoll werden.

\section{REFERENCES}

Arditil J., Koopowitz H., Jeffrey A.C., 1971. - David's reagent or the sugar content of orchid nectars. Am. Orch. Soc. Bull., 39, 1091-1092.

BAKER H.G., BAKER I., 1973 a. - Amino acids in nectar and their evolutionary significance. Nature, 241, 543-545.

Baker H.G., Baker I., 1973 b. - Amino acid production in nectar. In : Heywood V.H. ed., Taxonomy and Ecology, Academic Press, London, 243-264.

BaKer H.G., BAKER I., 1975. - Nectar constitution and pollinator-plant coevolution. In : Gilbert L.E. and Raven P.H. ed., Coevolution of animals and plants, University Texas Press, Austin, 100-140. 
BaKer H.G., BaKer I., 1977. - Intraspecific constancy of floral nectar amino acid complement. Bot. Gaz., 138, 183-191.

BASKIN S.I., Bliss C.A., 1969. - Sugar occurring in the extrafloral exudates of orchidaceae. Phytochemistry, 8, 1139-1145.

DARWIN C., 1877. - The various contrivances by which orchids are fertilized by insects, 2nd ed., D. Appleton \& Co., New York.

Frank H., JaEger H., 1985. - Capillary gas chromatography of amino acids. In : JaEger H. el., Glass capillary chromatography in medicine, clinical chemistry and pharmacology, Marcel Dekker, New York, 73-124.

GODFERY M.J., 1933. - Monograph and iconograph of native british orchidaceae, Cambridge University Press.

Harborne J.B., 1982. - Introduction to ecological biochemistry, 2nd ed. - Academic Press, London, New York, 57-65.

Jeffrey A.C., Arditti J., Koopowitz H., 1970. - Sugar content in floral and extrafloral exudates of orchids : pollination, myrmecology and chemotaxonomy implication. New Phytol., 69, 187-195.

Maurizio A., 1959. - Papierchromatographische Untersuchungen an Blütenhonigen und Nektar. Ann. Abeille, 4, 291-341.

Pais M.S.S., Chaves das Neves H.J., 1980. - Sugar content of the nectary exudate of Epipactis atropurpurea Rafin. Apidologie, 11, 39-45.

Percival M.S., 1961. - Types of nectars in angiosperms. New Phytol., 60, 235-281.

Percival M.S., 1965. - Floral Biology. - Pergamon Press, Oxford, New York.

Schomburg G., Husmann H., Borwitzky H., 1979. - Alquilpolysiloxane glass capillary columns combining high temperature stability of the stationary liquid and deactivation of the surface. Thermal treatment of dealkalinized glass surfaces by stationary liquid itself. Chromatographia, 12, 651-660.

VAN der PiJl L., Dodson C.H., 1966. - Orchid flowers. Their pollination and evolution. - University of Miami Press, Coral Glaves, Florida.

Vogel S., 1983. - Ecophysiology of zoophilic pollination in physiological plant ecology. In : Lange U.L., Nobel P.S., Osmond C.B. and Ziegler H. ed., Encyclopedia of plant physiology, Vol. 12 C New Series, Springer Verlag, Berlin, Heidelberg, 560-624.

Waller G.D., 1972. - Evoluting responses of honey bees to sugar solutions using an artificial flower feeder. Ann. Entomol. Soc. Amer., 65, 857-862.

Wiefelspütz W., 1970. - Über die Blütenbiologie der Gattung Epipactis. Jb. Naturw. Ver., Wuppertal, 23, 53-69.

Ziegler H., 1956. - Untersuchungen über die Leitung und Sekretion der Assimilate. Planta, 47, 447-500. 